\title{
The presence of Plio-Pleistocene palaeolama sp. (artiodactyla: camelidae) on the southern coast of Peru
}

Presencia de palaeolama sp. (artiodactyla: camelidae) del Pliopleistoceno en la costa sur del Perú

Présence du palaeolama sp. (artiodactyla: camelidae) du Pliopéistocène sur la côte sud du Pérou

Rodolfo Salas, Marcelo Stucchi and Thomas J. Devries

\section{CpenEdition}

Electronic version

URL: http://journals.openedition.org/bifea/6414

DOI: $10.4000 /$ bifea.6414

ISSN: 2076-5827

Publisher

Institut Français d'Études Andines

Printed version

Date of publication: 1 September 2003

Number of pages: $347-359$

ISSN: 0303-7495

\section{Electronic reference}

Rodolfo Salas, Marcelo Stucchi and Thomas J. Devries, « The presence of Plio-Pleistocene palaeolama sp. (artiodactyla: camelidae) on the southern coast of Peru », Bulletin de l'Institut français d'études andines [Online], 32 (2) | 2003, Online since 08 August 2003, connection on 10 December 2020. URL http://journals.openedition.org/bifea/6414 ; DOl : https://doi.org/10.4000/bifea.6414

\section{(c) $(1) \subseteq$}

Les contenus du Bulletin de l'Institut français d'études andines sont mis à disposition selon les termes de la licence Creative Commons Attribution - Pas d'Utilisation Commerciale - Pas de Modification 4.0 International. 


\title{
THE PRESENCE OF PLIO-PLEISTOCENE PALAEOLAMA SP. (ARTIODACTYLA: CAMELIDAE) ON THE SOUTHERN COAST OF PERU
}

\author{
Rodolfo SALAS ${ }^{* * *}$, Marcelo STUCCHI ${ }^{* *}$, Thomas J. DEVRIES $S^{* * *}$
}

\begin{abstract}
We report the oldest record of the genus Palaeolama in Peru; its constitutes one of the oldest records for the genus in South America. The shape and size of the fossil material is comparable to South American forms $P$. (Hemiauchenia) paradoxa and the smallest forms of $P$. (Palaeolama) weddellii. The bones were found within unnamed littoral marine deposits near Atiquipa, on the south coast of Peru. The occurrence of the extinct bivalve mollusk, Chlamys vidali, at the base of the section and coquinas of exclusively extant mollusks in the highest marine terrace capping the section indicates an age of about two million years. This age is slightly older or equal to the oldest records of $P$. (Palaeolama) in North America. The present report confirms that the Lamini were no strangers to Andean ecosystems prior to the Holocene.
\end{abstract}

Key words: Mammalia, Camelidae, Palaeolama, Plio-Pleistoceno, Atiquipa, Perú.

\section{PRESENCIA DE PALAEOLAMA SP. (ARTIODACTYLA: CAMELIDAE) DEL PLIO- PLEISTOCENO EN LA COSTA SUR DEL PERÚ}

\section{Resumen}

Se presenta el registro más antiguo del género Palaeolama en el territorio peruano y uno de los más antiguos de Sudamérica. La forma y tamaño del material conservado es comparable con las formas sudamericanas $P$. (Hemiauchenia) paradoxa y los especímenes más pequeños de P. (Palaeolama) weddellii. Procede de los depósitos marinos litorales innominados de Atiquipa, en la costa sur del Perú. La ocurrencia del molusco bivalvo extinto Chlamys vidali en la base de la sección y la coquina de moluscos actuales presentes en la terraza marina más alta que termina dicha sección, indicaría una edad aproximada de 2 millones de años. Esta edad es ligeramente mayor o igual a los registros más antiguos de P. (Palaeolama) en Norteamérica. El presente reporte confirma que los Lamini no fueron ajenos a los ecosistemas andinos antes del Holoceno.

Palabras claves: Mammalia, Camelidae, Palaeolama, Plio-Pleistoceno, Atiquipa, Perú.

* Instituto Francés de Estudios Andinos - IFEA, Casilla 18-1217 - Lima 18.

** Departamento de Paleontología de Vertebrados. Museo de Historia Natural - U.N.M.S.M. (Lima, Perú); E-mail por orden alfabético: rsalas@ifeanet.org, estuki@go.com.

**** Burke Museum of Natural History and Culture, University of Washington (Seattle, WA USA). 


\section{PRÉSENCE DU PALAEOLAMA SP. (ARTIODACTYLA: CAMELIDAE) DU PLIO- PÉISTOCÈNE SUR LA CÔTE SUD DU PÉROU}

\section{Résumé}

Nous présentons un spécimen du genre Palaeolama qui correspond au registre le plus ancien du genre sur le territoire péruvien ainsi que l'un des plus anciens en Amérique du Sud. La morphologie et la taille des éléments découverts sont comparables aux formes sudaméricaines $P$. (Hemiauchenia) paradoxa ainsi qu'aux formes les plus petites de P. (Palaeolama) weddellii. Ce spécimen provient des dépôts marins littoraux d'Atiquipa (côte sud-péruvienne). La présence du mollusque bivalve Chlamys vidali à la base de la section ainsi que de faluns coquilliers actuels, présents au niveau des terrasses marines les plus hautes qui terminent la section, correspondrait à un âge de 2 millions d'années. Cette date est légèrement supérieure ou égale aux registres les plus anciens de $P$. (Palaeolama) en Amérique du Nord. Cette découverte confirme que les Lamini étaient présents dans les écosystèmes andins avant l'Holocène.

Mots clés : Mammalia, Camelidae, Palaeolama, Plio-Pleistocène, Atiquipa, Pérou.

\section{INTRODUCTION}

The evolution of camelids took place principally in North America. Their migration to South America probably occurred during the late Pliocene (Hoffstetter, 1952). The earliest material was assigned tentatively to the Plio-Pleistocene of Argentina (Cabrera, 1935; Kraglievich, 1946; Marshall et al., 1984) and Uruguay (Mones, 1988).

Descriptions of the genera Palaeolama GervaIs, 1867, and Hemiauchenia Gervais \& Ameghino, 1880, were based on material collected from the Argentine Pampas. Cabrera (1935) and Hoffstetter (1952) agreed in considering Hemiauchenia as synonymous with Palaeolama. Webb (1974) distinguished Hemiauchenia from Palaeolama as a separate genus and tried both diagnosis. Most recently, Guérin \& Faure (1999) designated Hemiauchenia as a subgenus of Palaeolama.

The best documented and oldest account of P. (Palaeolama) from South America comes from the Ensenadan of Tarija, Bolivia (Webb \& Stehli, 1995). In contrast, $P$. (Hemiauchenia) was present in the upper Uquian, having immigrated during the second panamerican dispersal that occurred between 2,0 and 1,9 Ma (Marshall, 1985). In North America, P. (Hemiauchenia) is recognized from the Hemphillian (lower Pliocene), while P. (Palaeolama) is well represented in the Irvingtonian (lower Pleistocene) in shell banks from Leisey, Florida (Webb \& Stehli, 1995).

There are only two reliable reports of Palaeolama from the coast of Peru, both upper Pleistocene. The first report describes material from deposits of La Brea, near Talara (Lemon \& Churcher, 1961), which was assigned by Churcher (1965) and Webb (1974) to P. aequatorialis HoffstetTer, 1952. The second refers to material identified by Hoffstetter collected from the Pampa de los Fósiles, La Libertad (Marshall et al., 1984). 
The objective of this paper is to describe material of Palaeolama (sensu Guérin $\&$ Faure, 1999) from the Plio-Pleistocene of Peru and discuss its biostratigraphic and biogeographic implications.

The chronology of mammal ages for South America used in this study is that proposed by McKenna \& Bell (1997).

Institutional abbreviations:

MUSM: Museo de Historia Natural - Universidad Nacional Mayor de San Marcos, Lima.

UF: Florida Museum of Natural History - University of Florida, Florida.

\section{GEOLOGY AND AGE}

The camelid bones were found in an outcrop of conglomerate and bioclastic sandstone exposed in a roadcut along the Panamerican Highway on the northwestern side of Quebrada Infiernillo (SITE 596, Fig. 1). The lower part of the section $(6,6$ meters), which rests upon a seaward-tilting igneous platform; consists of a prograding sequence that represents shallow subtidal, lower shoreface, upper shoreface, and fluvial/alluvial environments characteristic of a high-energy beach fronting an attenuated flood-prone alluvial fan.

The middle part of the section (7,0 meters) is a transgressive succession of laminated bioclastic gravel, lenticular bioclastic gravel, and several meters of massive, poorly sorted, coarse-grained bioclastic sandstone with dispersed, transported whole fossils of mollusks, barnacles, and the camelid bones. The massive sands may had been accumulated in a small embayment at the mouth of Quebrada Infiernillo that captured debris washed in from the Pacific Ocean and down from the Andean foothills.

The upper part of the section includes a regressive sequence of cross-bedded bioclastic cobbly gravel and sandstone $(2,2 \mathrm{~m})$ overlain by a transgressive and regressive cycle (>3,2 meters) with similar deposits. A coquina that caps the second regressive sequence also constitutes the surface of the most elevated marine terrace, which stands 250 meters above sea level.

The oldest mollusks from the Atiquipa outcrop, disarticulated valves of Choromytilus chorus (MolinA, 1782) and Chlamys vidali (PHILIPPI, 1887), are wedged between boulders at the base of the section. $C$. vidali is found in lower and upper Pliocene strata of Chile (Herm, 1969), lower Pliocene shoreface deposits near Sacaco (Muizon \& DeVries, 1985), and on the surface of the oldest marine terraces of northern and southern Peru (DeVries, 1986). Absent from the base of the Atiquipa section are mollusks that signify a lower Pliocene age, e.g., Acanthina 'triangularis' Devries, 1986; Herminespina mirabilis (PHILIPPI, 1887); H. saskiae Devries \& VermeiJ, 1997; Concholepas kieneri Hupe, 1859; and C. nodosa Moricke, 1896 (Devries \& Vermeij, 1997; Devries, 2000). 


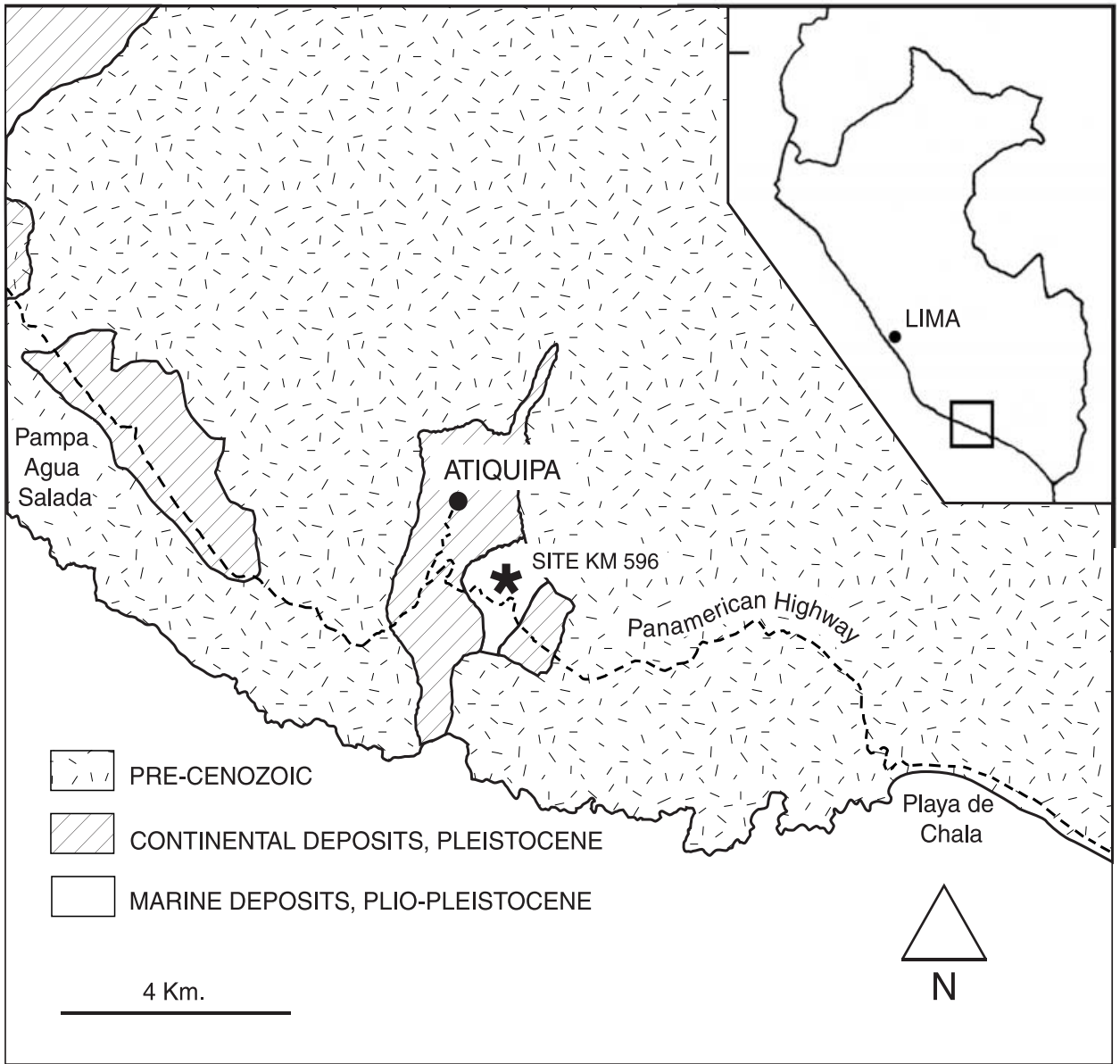

Fig. 1 - Map of the area of Atiquipa showing "SITE 596" where the camelid material was found.

The bone-bearing sandstones contain an assemblage of mollusks that includes Concholepas camerata Devries, 2000, which indicates a latest Pliocene or early Pleistocene age. The coquina that caps the section at Atiquipa contains an assemblage of the extant mollusks Glycymeris ovata (BRODERIP, 1832), Eurhomalea lenticularis (Sowerby, 1835), Mulina edulis (KING, 1831), and Oliva peruviana LAMARCK, 1811. Elsewhere along the coast between Chala and Camaná, these species occur in a comparable geological setting together with the extinct gastropod, Chorus grandis (PHILIPPI, 1887), suggesting a pre-Pleistocene age (Devries, 1997) (Fig. 2). 


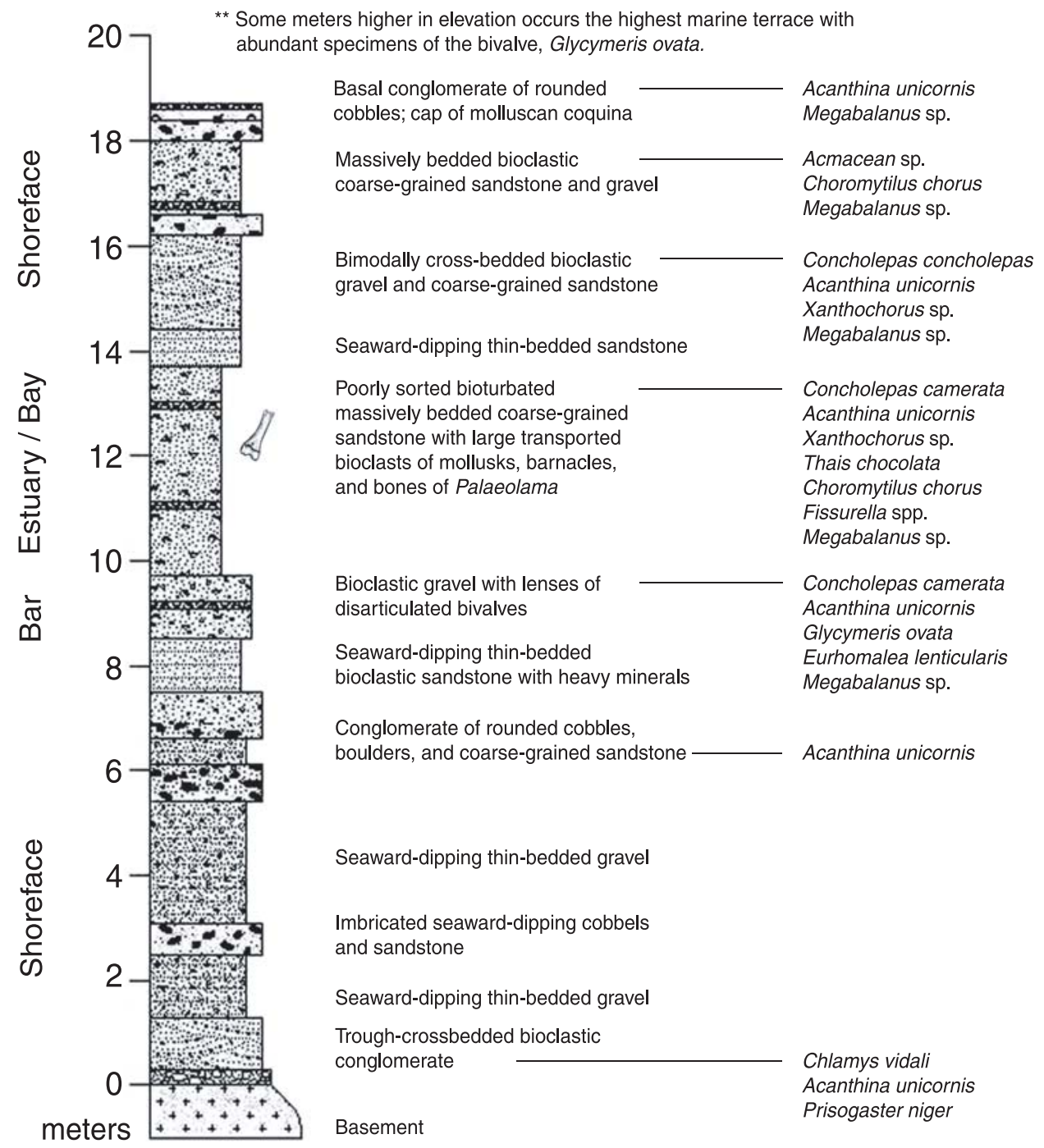

Fig. 2 - Stratigraphic column of the "SITE 596" section near Atiquipa. 


\section{SYSTEMATIC PALEONTOLOGY}

Order ARTIODACTYLA OwEN, 1848

Family CAMELIDAE GRAY, 1821

Subfamily CAMELINAE GRAY, 1821

Tribe LAMINI WEBB, 1965

Palaeolama GERVAIS, 1867

Material - MUSM 51 - Departamento de Paleontología de Vertebrados, Museo de Historia Natural (UNMSM); associated distal portions of the left femur and right humerus without the proximal epiphysis. Collected by Thomas DeVries and Marcelo Stucchi.

Locality - 15'48'42"S, 74²1'25"W; SITE 596, Atiquipa (Panamerican Highway, km. 596 south), 200-250 meters above sea level, Arequipa Department, Peru.

Age - Late Pliocene to earliest Pleistocene (2,2 - 1,6 Ma).

\section{1. Description}

Humerus - In the humerus MUSM 51 (Fig. 3 A, B), the lateral epicondyle is more robust than the medial epicondyle, in contrast to that of Vicugna vicugna MolinA, 1782, where the two are subequal. From a cranial perspective, the articular trochlea is compressed proximodistally. The interlabial longitudinal distance-distal articular transversal distance index in MUSM 51 is 39; in V. vicugna it is 48. The axial throat is deep. In relation to the medial lip, the lateral lip extends proximally more than in $V$. vicugna and $P$. weddellii. The epiphyses of the lateral and medial epicondyles are partially fused.

The preserved part of the MUSM 51 humerus does not exhibit significant differences in shape or proportion from any of the Palaeolama species. Among the southamerican species, it is practically equal in size to the smallest forms of $P$. weddellii Gervais, 1855 of the Pleistocene of Ecuador (Hoffstetter, 1952) and the average of P. paradoxa (Gervais \& Ameghino, 1880). P. major Lias, 1872 has only been able to be compared in one of its dimensions. The total length of the MUSM 51 humerus is estimated to be 270-300 mm (Table 1).

Femur - The distal epiphysis of the MUSM 51 femur is robust (Fig. 3 C). The femoral trochlea is symmetrical and perfectly parallel with the axial axis. Although the lateral condyle is only partially preserved, it can be seen to be larger than the medial condyle.

As mentioned for the humerus, the form and proportions of the femur are similar to those of $P$. weddellii from Ecuador (Hoffstetter, 1952) and P. paradoxa (Cabrera, 1935). Its estimated maximum transverse diameter is slightly less than the minimum value for $P$. weddellii (Table 2). The material of $P$. major of Winge (1906) has proven to be that of a juvenile individual (Hoffstetter, 1952). As evidenced by the dimensions of a femur of P. major from Brazil (Guérin \& Faure, 1999), the distal epiphysis does not have the same proportions (Fig. 3). 
Table 1 - Comparative dimensions of the humerus of Palaeolama sp. (MUSM 51). TL - total length; PTD - proximal transversal diameter; DTD - distal transversal diameter; DATD - distal articular transversal diameter; MTDD - maximum transversal diameter of the diaphysis (Dimensions in $\mathbf{m m}$ ).

\begin{tabular}{|c|c|c|c|c|c|c|}
\hline \multicolumn{3}{|r|}{ TL-var } & \multirow{2}{*}{$\begin{array}{c}\text { PDT-var } \\
-\end{array}$} & \multirow{2}{*}{$\begin{array}{c}\text { DID-var } \\
63,2\end{array}$} & \multicolumn{2}{|c|}{ DATD-var MTDD-var } \\
\hline Palaeolama sp. & MUSM 51 & - & & & 56 & 30,4 \\
\hline $\begin{array}{c}\text { P. }(\text { Palaeolama }) \\
\text { weddellii }\end{array}$ & $\begin{array}{c}\text { Hoffstetter, } 1956 \\
\text { Guérin \& Faure, } 1999\end{array}$ & $\begin{array}{c}302-316 \\
278\end{array}$ & $\begin{array}{c}81-92 \\
83,5\end{array}$ & $\begin{array}{c}65,2-79 \\
68,5\end{array}$ & $\begin{array}{c}54-64,5 \\
-\end{array}$ & $\begin{array}{c}- \\
32,5\end{array}$ \\
\hline $\begin{array}{c}\text { P. }(\text { Hemiauchenia }) \\
\text { paradoxa }\end{array}$ & $\begin{array}{c}\text { Cabrera, } 1935 \\
\text { Guérin \& Faure, } 1999\end{array}$ & $\begin{array}{c}279-297 \\
270\end{array}$ & $\begin{array}{c}76-81 \\
74\end{array}$ & $\overline{61,5}$ & $\begin{array}{c}57-60 \\
-\end{array}$ & $\begin{array}{c}- \\
30\end{array}$ \\
\hline $\begin{array}{c}\text { P. }(\text { Hemiauchenia }) \\
\text { major }\end{array}$ & Winge, 1906 & 261 & 79 & - & $47-54,5$ & - \\
\hline $\begin{array}{c}\text { P. }(\text { Hemiauchenia }) \\
\text { niedae }\end{array}$ & Guérin \& Faure, 1999 & \multicolumn{3}{|c|}{$325-348$ 79,5-93,570,5-82,5 } & - & $36,5-43$ \\
\hline \multirow{5}{*}{$\begin{array}{c}\text { P. (Hemiauchenia) } \\
\text { macrocephala } \\
\text { Inglis, Florida }\end{array}$} & UF 179748 & 329 & $\sim 81$ & 67 & 61 & 37 \\
\hline & UF 45478 & 326 & 83 & 66 & 61 & 36 \\
\hline & UF179744 & - & - & 62,5 & 56 & 33 \\
\hline & UF 45480 & - & - & 67 & 60 & 32 \\
\hline & UF 176912 & - & - & 66 & 60 & 35 \\
\hline \multirow{7}{*}{$\begin{array}{l}\text { Palaeolama sp.** } \\
\text { Leisey Shell Pits, } \\
\text { Florida }\end{array}$} & UF 65323 & - & - & 68 & 60 & 34 \\
\hline & UF 66487 & 307 & - & 65 & 61 & 36 \\
\hline & UF 66490 & 304 & 81 & 71 & 60 & 36 \\
\hline & UF 80400 & - & - & 65 & 55 & 31 \\
\hline & UF 80493 & - & - & 67 & 57 & 30 \\
\hline & UF 83661 & 301 & 84 & 64 & 61 & 33 \\
\hline & UF 85018 & 306 & 83 & 67 & 61 & 36 \\
\hline
\end{tabular}

** The specimens may belong to either $P$. (Palaeolama) mirifica or $P$. (Hemiauchenia) seymourensis.

\section{2. Discussion}

Abundant material assigned to Palaeolama and "Auchenia" from Miramar, Argentina, is referred to the Chapadmalalian by Cabrera (1935) and Kraglievich (1946). Nevertheless, Marshall et al. (1983) did not include the family Camelidae among mammals of Holarctic origin assigned to the Chapadmalalian of Argentina. Later, Marshall et al. (1984) characterized the Uquian (lower Pleistocene) by the presence of Camelidae, among other families. The occurrence of Palaeolama (sensu Guérin \& Faure, 1999) in upper Pliocene-lower Pleistocene deposits of coastal southern Peru 
Table 2 - Comparative dimensions of the femur of Palaeolama sp. (MUSM 51). ML medial length; LL - lateral length; DTD - distal transversal diameter; PTD - proximal transversal diameter; DAPD - distal antero-posterior diameter (Dimensions in mm).

\begin{tabular}{|c|c|c|c|c|c|c|}
\hline & & ML-var & LL-var & PTD-var & DTD-va & DAPD-var \\
\hline Palaeolama sp. & MUSM 51 & - & - & - & $\sim 80$ & 84 \\
\hline $\begin{array}{c}\text { P. }(\text { Palaeolama }) \\
\text { weddellii }\end{array}$ & Hoffstetter, 1956 & $369-400,5$ & $358-394$ & $94,5-113$ & $83-92,5$ & 88,5 \\
\hline $\begin{array}{c}\text { P. }(\text { Hemiauchenia }) \\
\text { paradoxa }\end{array}$ & Cabrera, 1935 & $\sim 370$ & - & 90 & 79 & - \\
\hline $\begin{array}{c}\text { P. }(\text { Hemiauchenia }) \\
\text { major }\end{array}$ & $\begin{array}{c}\text { Winge, } 1906 \\
\text { Guérin \& Faure, } 1999\end{array}$ & $\begin{array}{l}357 \\
384^{*}\end{array}$ & - & $\begin{array}{c}86-95 \\
-\end{array}$ & $\begin{array}{l}79 \\
89\end{array}$ & $\begin{array}{c}- \\
88\end{array}$ \\
\hline $\begin{array}{c}\text { P. }(\text { Hemiauchenia }) \\
\text { niedae }\end{array}$ & Guérin \& Faure, 1999 & $443^{*}$ & - & $101-107$ & $85-92$ & $89,5-94$ \\
\hline $\begin{array}{c}\text { P. }(\text { Hemiauchenia }) \\
\text { macrocephala } \\
\text { Inglis, Florida }\end{array}$ & $\begin{array}{l}\text { UF } 179749 \\
\text { UF } 179750 \\
\text { UF } 45279\end{array}$ & $\begin{array}{l}- \\
- \\
-\end{array}$ & $\begin{array}{l}- \\
- \\
-\end{array}$ & $\begin{array}{l}- \\
- \\
-\end{array}$ & $\begin{array}{l}93 \\
83 \\
83\end{array}$ & $\begin{array}{l}98 \\
89 \\
87\end{array}$ \\
\hline $\begin{array}{l}\text { Palaeolama sp.** } \\
\text { Leisey Shell Pits, } \\
\text { Florida }\end{array}$ & $\begin{array}{l}\text { UF } 66500 \\
\text { UF } 66602 \\
\text { UF } 64331 \\
\text { UF } 66601 \\
\text { UF } 66603 \\
\text { UF } 66604 \\
\text { UF } 68884\end{array}$ & $\begin{array}{c}377 \\
- \\
- \\
373 \\
- \\
- \\
-\end{array}$ & $\begin{array}{c}\sim 375 \\
- \\
- \\
369 \\
- \\
- \\
-\end{array}$ & $\begin{array}{c}100 \\
- \\
- \\
101 \\
- \\
- \\
-\end{array}$ & $\begin{array}{c}82 \\
82 \\
\sim 81 \\
85 \\
\sim 86 \\
82 \\
86\end{array}$ & $\begin{array}{l}87 \\
83 \\
90 \\
89 \\
95 \\
86 \\
87\end{array}$ \\
\hline
\end{tabular}

* These measurements correspond to the maximum length of the bone.

*** The specimens may belong to either $P$. (Palaeolama) mirifica or $P$. (Hemiauchenia) seymourensis.

confirms the presence of camelids, particularly of Palaeolama, in the Uquian, as was also noted by Mones (1988) based on evidence of associated fauna from Uruguay. Owing to these records, the Uquian Age (characterized by various first appearances of mammals in Argentina) can be extended, at least with respect to the Camelidae, to Peru and Uruguay. The Peruvian material has an age similar to that of the oldest occurrence of P. (Palaeolama) in North America, referred to the Irvingtonian of Leisey, Florida (Webb \& Stehli, 1995). The existence of P. (Hemiauchenia) is pushed back to the Hemphillian (Webb \& Stehli, 1995).

P. (Palaeolama) is distinguished from P. (Hemiauchenia) principally by the proportion and size of its limb bones (Webb, 1974; Webb \& Stehli, 1985; Guérin \& Faure, 1999). Nevertheless, a morphological analysis of the fossil material does not reveal a distinction within the genus. All Palaeolama species show important 


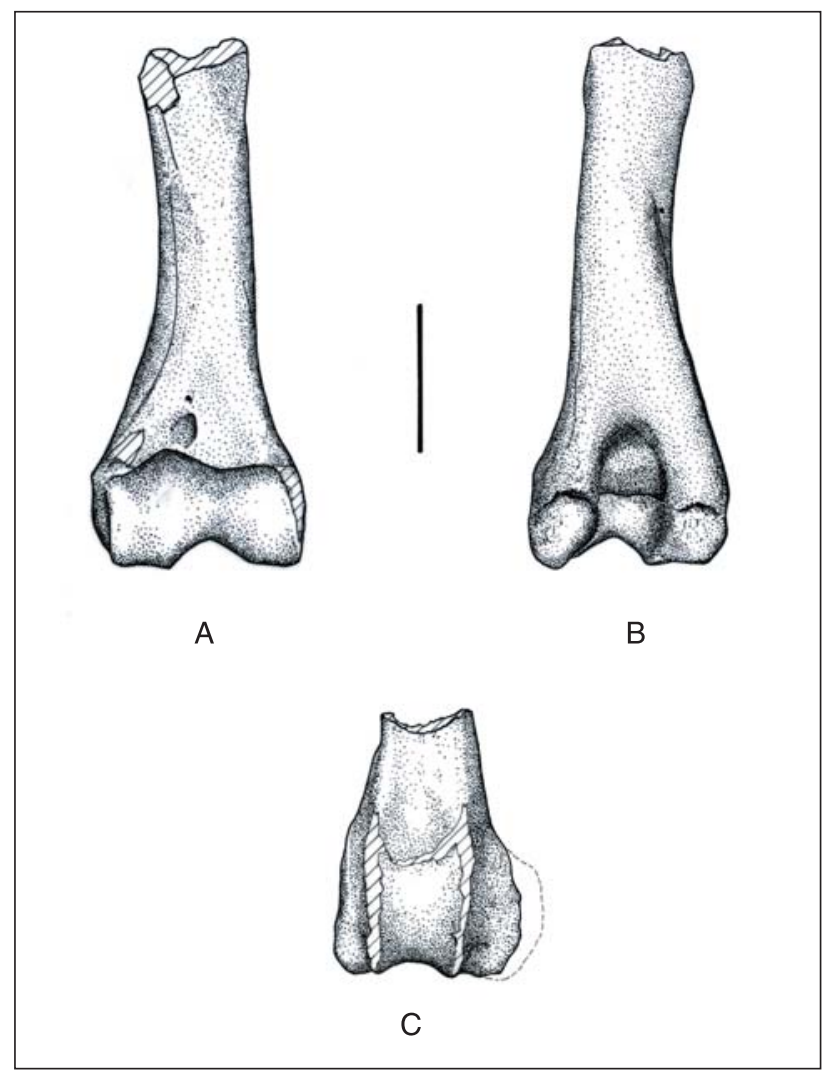

Fig. 3 - Palaeolama sp., MUSM 51. A-B. Right humerus: $A$, anterior view; $B$, posterior view. $C$. Left femur, anterior view (Scale $5 \mathrm{~cm}$ ).

intraespecific variation in size and also are indistinguishable in humerus and femur proportions (Table 1 and 2, Figs. 4 and 5). In localities like Leisey Shell Pits, Florida, where $P$. (Palaeolama) and P. (Hemiauchenia) are present, complete humerus and femur could not be assigned to infra-generic level. However, a morphological analysis of humerus and femur remains from Peru indicate that they are comparable in proportion and size with southamerican P. (Hemiauchenia) paradoxa and the smallest forms of P. (Palaeolama) weddellii. Additionally, this can be extended to the smallest specimens of northamerican P. (Palaeolama) mirifica, P. (Hemiauchenia) seymourensis and $P$. (Hemiauchenia) macrocephala. Considering that the peruvian material might be from a young adult (see below), the measurements could be slightly less than those for a completely mature individual (Figs. 4 and Fig. 5).

Other points of distinction between $P$. (Palaeolama) and $P$. (Hemiauchenia) are habitat and diet. While $P$. (Palaeolama) was a browser with robust metapods that lived in montagne regions, $P$. (Hemiauchenia) had a mixed diet (browsing and grazing) and gracile metapods suitable to living on the open plains (Webb, 1974; Webb \& Stehli, 


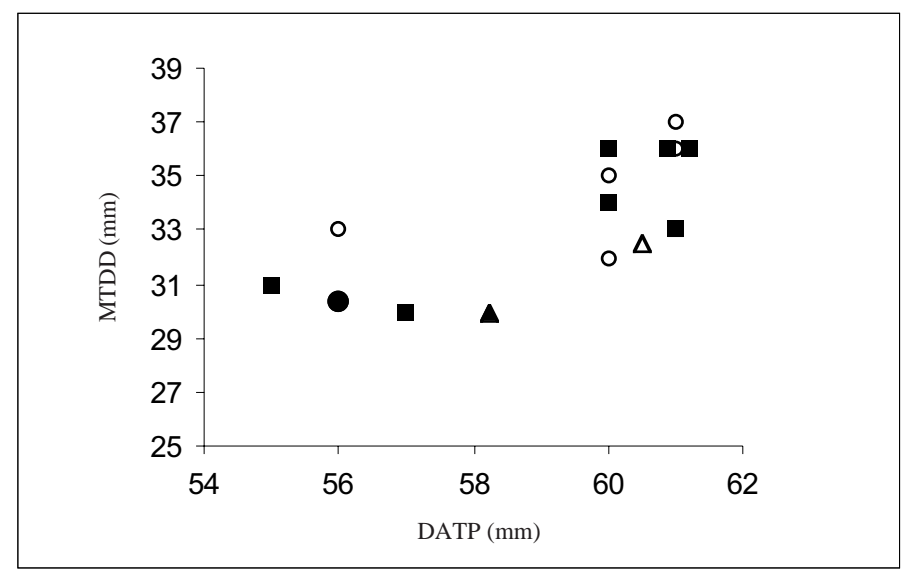

MUSM 51

$\Delta P$. weddellii

A P. paradoxa

O P. macrocephala

- Palaeolama sp.*

* The specimens may belong to either P. (Palaeolama) mirifica or P. (Hemiauchenia) seymourensis; Loc. Leisey Shell Pits, Florida.

Fig. 4 - Scatter diagram in milimeters of MTDD (maximum transversal diameter of the diaphysis) versus DATD (distal articular transversal diameter) in humerus of

MUSM 51 and species of Palaeolama from South and North America. In $P$. weddellii and $P$.paradoxa the dimension is an average.

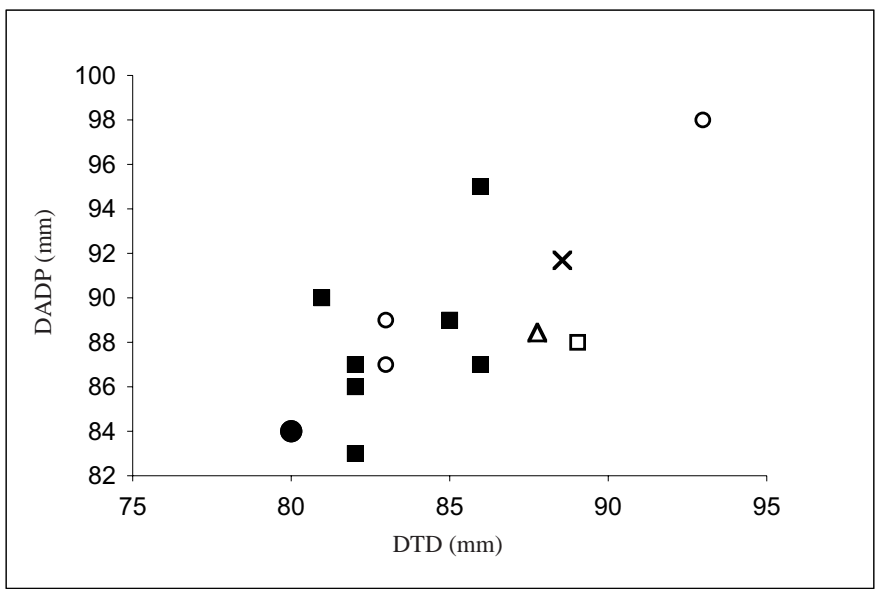

- MUSM 51

$\Delta$ P. weddellii

$\mathrm{x} P$. niedae

$\square$ P. major

P. macrocephala

Palaeolama sp.*

${ }^{*}$ The specimens may belong to either P. (Palaeolama) mirifica or P. (Hemiauchenia) seymourensis; Loc. Leisey Shell Pits, Florida.

Fig. 5 - Scatter diagram in milimeters of DAPD (distal antero-posterior diameter) versus DTD (distal transversal diameter) in femur of MUSM 51 and species of Palaeolama from South and North America. In $P$. weddellii the dimension is an average. 
1995). The fossil record of both subgenera, the rugged relief, and the desert character of the Peruvian coast since the middle Miocene (Sébrier et al., 1984; Alpers \& Brimhall, 1988) suggest that the Lamini from Atiquipa was a P. (Palaeolama)-like camelid.

MUSM 51 (portions of femur and humerus) was found associated in the same section of the outcrop. Preceding statement and their relative size suggest that both belong to a single individual. However, the bone fusion secuence does not correspond. In modern camelids, the fusion of the epiphyses of the distal epicondyles of the humerus takes place between an age of 12 and 18 months (Wheeler, 1999). The epiphyses are not completely fused in sample MUSM 51, which suggests it belongs to a young individual. The distal epiphysis of the femur of MUSM 51, however, is completely fused, contradicting the aforementioned suggestion. In modern camelids, the fusion of epiphyses in the femur happens at an age of 42 to 44 months, when the animal is a young adult (Wheeler, 1999). According to Wheeler (personal communication, 2000), exceptional cases do occur in modern camelids in which the fusion of the epiphyses of the distal epicondyles in the humerus never occurs due to certain environmental conditions. In light of these comparisons, we consider MUSM 51 could belong to an individual older than a young adult.

The nearshore marine sediments which yielded MUSM 51 were deposited near the mouth of a canyon and a mountainous escarpment. We propose that the bones could have been transported by a river from the mountains to the coast. The fragmentary nature of the bones is consistent with high-energy transport. Thus, Palaeolama sp. might have inhabited both the Pacific coast and Andean mountains, as presently does the guanaco, Lama guanicoe (MulLeR, 1776) according to Wheeler (1999). Ochsenius (1995) contends that the Lamini did not truly exploit Andean ecosystems prior to the Holocene. The occurrence of MUSM 51 in Plio-Pleistocene strata, as well as recent discoveries of Lama guanicoe in upper Pleistocene levels from the Peruvian coast (Salas \& Stucchi, 2002) challenges that claim. We propose that the rarity of Pleistocene camelid material in the region is due to a scarcity of outcrop, rather than a failure of camelids to exploit pre-Holocene Andean environments.

\section{Acknowledgments.}

The authors wish to thank Christian de Muizon (Muséum National d'Histoire Naturelle, Paris) for his critique revision of the manuscript and valuable suggestions; Jane Wheeler (Universidad Nacional Mayor de San Marcos, Lima) for her comments about the ontogeny of modern camelids; René Marocco (Institut de recherche pour le développement, Lima) and François Pujos (Instituto Francés de Estudios Andinos, Lima) for their helpful insights; Bruce MacFadden and Richard Hulbert of Florida Museum of Natural History for providing access to the vertebrate paleontology collection. We would like to thank A. Cisneros, J. Tejada and D. Omura. We also thank Jean Vacher (Director - Instituto Francés de Estudios Andinos, Lima) and Niels Valencia (Director - Museo de Historia Natural - UNMSM, Lima) for their continued support of this research. 


\section{References cited}

ALPERS, C. \& BRIMHALL, G., 1988 - Middle Miocene climatic change in the Atacama Desert, northern Chile: Evidence from supergene mineralization at La Escondida. Geological Society of American Bulletin, 100: 1640-1656.

CABRERA, A., 1935 - Sobre la Osteología de Palaeolama. Anales del Museo Argentino de Ciencias Naturales "Bernardino Rivadavia” 66 Paleontología de Vertebrados, 38: 283312.

CHURCHER, C., 1965 - Camelid material of the genus Palaeolama Gervais from the Talara Tar Seeps, Perú, with a description of a new subgenus Astylolama. Proceedings of the Zoological Society of London, 145: 161-205.

DEVRIES, T., 1986 - Geology and paleontology of tablazos in Northwest Peru. Unpublished dissertation, Ohio State University, Columbus, Ohio, 964p.

DEVRIES, T., 1997 - A review of the genus Chorus Gray, 1847 (Gastropoda: Muricidae) from western South America. Tulane Studies in Geology and Paleontology, 30(3): 125-147.

DEVRIES, T., 2000 - Two new Neogene species and the evolution of labral teeth in Concholepas Lamarck, 1801 (Neogastropoda: Muricoidea). The Veliger, 43(1): 43-50.

DEVRIES, T. \& VERMEIJ, G., 1997 - Herminespina: New genus of Neogene muricid gastropod from Peru and Chile. Journal of Paleontology, 71(4): 610-615.

GUÉRIN, C. \& FAURE, M., 1999 - Palaeolama (Hemiauchenia) niedae nov. sp., nouveau Camelidae du nordeste brésilien et sa place parmi les Lamini d'Amérique du Sud. Geobios, 32(4): 629-659.

HERM, D., 1969 - Marines Pliozän und Pleistozän in Nord- und Mittel-Chile unter besonderer Berücksichtigung der Entwicklung der Mollusken-Faunen. Zitteliana, 2: 1-159.

HOFFSTETTER, R., 1952 - Les mammifères Pléistocènes de la République de l'Équateur. Mémoires de la Societé Géologique de France, 66: 1-391.

KRAGLIEVICH, L., 1946 - Sobre camélidos Chapadmalenses. Notas del Museo de La Plata Paleontología, 11(93): 317-329.

LEMON, R. \& CHURCHER, C., 1961 - Pleistocene geology and paleontology of the Talara region, Norwest Peru. American Journal of Science, 259(6): 410-429.

MCKENNA, M. \& BELL, S., 1997 - Classification of the Mammals above the species level. 631 p.; New York: Columbia University Press.

MARSHALL,L., 1985 - Geochronology and Land Mammal Biochronology of the Transamerican Faunal Interchange: In: F. G. Stehli \& S. D. Webb (eds.), The Great American Biotic Interchange: $49-85$.

MARSHALL, L., BERTA, A., HOFFSTETTER, R., PASCUAL, R., REIG, O., BOMBÍN, M. \& MONES, A., 1984 - Mammals and Stratigraphy: Geochronology of the Continental Mammal-Bearing Quaternary of South America. Palaeovertebrata, 76p. Mémoire Extraordinaire.

MARSHALL, L., HOFFSTETTER, R. \& PASCUAL, R., 1983 - Mammals and Stratigraphy: Geochronology of the Continental Mammal-Bearing Tertiary of South America. Palaeovertebrata, 93p.. Mémoire Extraordinaire.

MONES, A., 1988 - Nuevos registros de mamíferos fósiles de la Formación San José (PliocenoPleistoceno inferior) (Mammalia: Xenarthra; Artiodactyla; Rodentia). Comunicaciones Paleontológicas del Museo de Historia Natural de Montevideo, 1(20): 255-277.

MUIZON, C. de \& DEVRIES, T., 1985 - Geology and paleontology of the Pisco Formation in the area of Sacaco, Peru. Geologische Rundschau, 74(3): 547-563.

OCHSENIUS, C., 1995 - Late Pleistocene paleoecology of the south american aridity. A case of continental dichotomy and the search of a new paradigm in paleoclimatology. In: Cambios Cuaternarios en América del Sur (J. Argollo \& Ph. Mourguiart eds.): 3-27. 
SALAS, R. \& STUCCHI, M., 2002 - Reporte preliminar de Lama guanicoe (Mammalia, Artiodactyla, Camelidae) en el Pleistoceno Superior de Aguada de Lomas, Arequipa. XI Congreso Peruano de Geología, Lima.

SEBRIER, M., MAROCCO, R. \& MACHARÉ, J., 1984 - Evolution Cenozoique du Plémont Pacifique et ses relations avec la Cordillère des Andes dans le Pérou central et méridional. Colloque "Montagnes et Plémonts", R.G.P.S.O.: 49-69.

WEBB, D., 1974 - Pleistocene Llamas of Florida, with a brief review of the Lamini. In: Pleistocene Mammals of Florida (S.D. Webb ed.): 170-259; Gainesville: University of Florida Press.

WEBB, D. \& STEHLI, F., 1995 - Selenodont Artiodactyla (Camelidae and Cervidae) from the Leisey Shell Pits, Hillsborough County, Florida. Bulletin of the Florida Museum of Natural History, No 37 Vol. 2, 19: 621-643.

WHEELER, J., 1999 - Patrones Prehistóricos de Utilización de los Camélidos Sudamericanos. Boletín de Arqueología PUCP, 3: 297-305.

WINGE, H., 1906 - Jordfundne og nulevende Hovdyr (Ungulata) fra Lagoa Santa, Minas Geraes, Brasilien. Med Udsigt over Hovdyrenes indbyrdes Slaegtskab. E. Museo Lundii, 3(1): $1-239$. 
Institut Français d'Études Andines - Museo de Arte de Lima Pedidos: IFEA, Casilla 18-1217, Lima 18 - Perí, Tel. 4476070 Fax: 4457650 - E-mail: postmasterlifea.org.pe

Web: http://www.ifeanet.org 